\title{
O.O. БІЛИК
}

Олександра Олегівна Білик, кандидат юридичних наук

ORCID: 0000-0001-8828-8931

\section{ПИТАННЯ, ПОВ'ЯЗАНІ 3 РОЗІРВАННЯМ ШЛЮБУ, У ПРАКТИЦІ ЄВРОПЕЙСЬКОГО СУДУ З ПРАВ ЛЮДИНИ}

Постановка проблеми. Дослідження практики Європейського суду з прав людини (далі - ЄСПЛ, Суд) посідає чільне місце в роботах українських науковців. Все більше теоретиків і практиків різних галузей права звертаються до неї. Дана тенденція зумовлена, зокрема, тим, що відповідно до ст. 17 Закону України «Про виконання рішень та застосування практики Європейського суду з прав людини 1 українські суди застосовують при розгляді справ Конвенцію про захист прав людини і основоположних свобод (далі - Конвенція) та практику Суду як джерело права.

Серед інших прав, Конвенція² у ст. 12 закріплює право на шлюб, а саме: чоловік і жінка, які досягли шлюбного віку, мають право на шлюб і створення сім'ї згідно з національними законами, які регулюють здійснення цього права. Закріплюючи право на шлюб, дана стаття не закріплює можливості його припинити шляхом розірвання.

Розірвання шлюбу можна визначити як санкціоноване компетентним органом вольове припинення шлюбного зв'язку між особами за життя обох з подружжя, який має наслідком припинення на майбутнє прав та обов'язків подружжя.

Якщо звернутися до українського законодавства, то в Сімейному кодексі Україниз (далі - СК) зазначено, що шлюб припиняється внаслідок його розірвання (ч. 2 ст. 104 СК). Більше того, на законодавчому рівні закріплено, що кожен із подружжя має право припинити шлюбні відносини (ч. 3 ст. 56 СК).

Незважаючи на те, що можливість розірвати шлюб прямо не передбачена Конвенцією, питання наявності у особи, яка перебуває у шлюбі такого права, а також перешкоджання особам зробити це з боку держави розглядалися ЄСПЛ неодноразово. I хоча практика Суду в цьому аспекті не настільки об'ємна, як 3 інших питань, вона все ж існує і потребує аналізу для кращого розуміння.

Аналіз останніх досліджень і публікацій. У юридичній літературі останнім часом стали більш докладно досліджувати питання розгляду справ Судом саме у сфері сімейно-правових відносин між особами. У даному аспекті слід згадати дисертаційне дослідження М.М. Слабан, наукові статті Л.В. Красицької, М.В. Логвінової, Л.І. Радченко, О.А. Явор.

Мета статті. Виходячи з практики ССПЛ, з'ясувати, чи визнається право на розірвання шлюбу нарівні 3 правом на шлюб, закріпленим у ст. 12 Конвенції, а також підстави визнання порушення права на шлюб осіб, які не можуть розірвати свій шлюб з метою укладення нового шлюбу з іншою особою чи зміни свого сімейного статусу.

Виклад основного матеріалу. Одним із перших і найбільш значущих рішень у цьому аспекті $є$ рішення у справі «Джонстон та інші проти Ірландії». Відповідно до Конституції Ірландії (в редакції, яка діяла на той час), перший заявник не міг розірвати свій перший шлюб, що дало б йому змогу одружитися з жінкою, 3 якою він проживав протягом тривалого часу (другий заявник) і з якою мав дочку (третій заявник).

Заявники констатували, що стосовно цієї справи центральним питанням було не те, чи Конвенція гарантувала право на розлучення, а чи той факт, що вони не могли одружитися одне з одним, був сумісним із правом на шлюб чи повторний шлюб та 3 правом на повагу до сімейного життя, закріпленим у ст. ст. 12 та 8 (право на повагу до приватного і сімейного життя) Конвенції. Суд зазначив, що у будь-якому суспільстві, яке підтримує принцип моногамії, немислимо, що перший заявник повинен мати можливість одружитися до того часу, поки його шлюб з першою дружиною не буде розірвано. Друга заявниця, зі свого боку, не скаржилася на загальну неможливість укласти шлюб, а скоріше на неможливість укласти шлюб з першим заявником, ситуацію, що випливає саме $з$ того, що він не міг отримати розлучення. Отже, їхню справу не можна розглядати окремо від проблеми недоступності розлучення.

Суд наголошує, що для тлумачення ст. 12 Конвенції слід звернутися до історії іï формулювання. Так, при підготовці тексту цієї статті за основу було взято текст ст. 16 Загальної декларації прав людини, де в ч. 1 зазначено таке: «Чоловіки і жінки, які досягли повноліття, мають право без будь-яких обмежень за ознакою раси, національності або релігії одружуватися і засновувати сім'ю. Вони користуються однаковими правами щодо одруження, під час шлюбу та під час його розірвання».

Роз'яснюючи Консультативній асамблеї, чому проєкт майбутньої ст. 12 не включає слова, які містяться в останньому реченні вищезазначеного пункту, пан Тейтген, доповідач Комітету з правових та адміністративних питань, зазначив: «Згадуючи конкретну статтю Загальної декларації, ми використовували лише ту

(c) О.О. Білик, 2020

* Oleksandra Bilyk, Ph.D. in Law 
частину пункту цієї статті, яка підтверджує право на шлюб та створення сім’ї, але не наступні положення цієї статті щодо рівних прав після шлюбу, оскільки ми гарантуємо лише право на шлюб».

Виходячи з вищезазначеного, на думку Суду, при формулювання ст. 12 не було ніякої мети гарантувати право на розірвання шлюбних зв'язків шляхом розлучення ${ }^{4}$.

Стосовно ст. 16 Декларації, то слід погодитися з тими науковцями, які зазначають, що текст ст. 16 Декларації не включає як таке право на розлучення, а лише закріплює, що чоловіки і жінки мають однакові права в цьому відношенні. Якщо жодному з них не надано право на розлучення, вони мають рівні права в цьому відношенні. Водночас це положення прямо забороняє законодавство, згідно з яким чоловікові дозволяється подавати на розлучення, тоді як жінці - ні 5 .

У рішенні у справі також робиться наголос на тому, що право на розлучення не включено в Протокол № 7 до Конвенції, який був відкритий для підписання 22 листопада 1984 р. У ст. 5 Протоколу 7, який гарантує подружжю певні додаткові права, особливо у разі розірвання шлюбу, не було використано можливості вирішити це питання. Рівноправність кожного з подружжя, закріплена у вищезазначеній статті, визначає, що кожен з подружжя у відносинах між собою і в їхніх відносинах зі своїми дітьми користується рівними правами та обов'язками цивільного характеру, що виникають зі вступу у шлюб, перебування в шлюбі та у випадку його розірвання 6 .

Суд зазначає, що в п. 39 пояснювальної доповіді до Протоколу 7 також роз’яснюється, що слова «у разі його розірвання», котрі містяться у ст. 5, «не передбачають жодних зобов’язань перед державою передбачити розірвання шлюбу або надати будь-які особливі форми розірвання».

Таким чином, у рішенні у справі «Джонстон та інші проти Ірландії» Суд дійшов висновку, що заявники не можуть виокремити право на розлучення зі ст. 12 Конвенції

В іншому рішенні ЄСПЛ звертався до питання встановлення часових обмежень стосовно того, скільки часу має пройти після розірвання попереднього шлюбу, щоб особа могла укласти повторний шлюб. У справі «Ф. проти Швейцарії» розглядалося питання тимчасової заборони укласти повторний шлюб, яка була накладена на заявника після його третього розлучення згідно з чинною на той час нормою швейцарського Цивільного кодексу. Суд не погодився з аргументом, що тимчасова заборона укладення повторного шлюбу спрямована на збереження прав інших, зокрема майбутніх з подружжя попередньо розлученої особи. Тому дане обмеження вплинуло на саму сутність права на шлюб, було непропорційним до законодавчо визначеної мети і порушило ст. 12 Конвенції.

У даному рішенні міститься зіставлення 3 проаналізованою вище справою «Джонстон та інші проти Ірландії». Так, спростовуючи аргументи Уряду, Суд зазначає, що ситуація заявника Ф. дуже відрізняється від ситуації містера Джонстона, оскільки те, що було спірним у випадку останнього, було право чоловіка, який ще був одружений, на розірвання шлюбу. Якщо ж національне законодавство дозволяє розлучення, що не $\epsilon$ вимогою Конвенції, ст. 12 забезпечує розлученим особам право на повторний шлюб без необгрунтованих обмежень ${ }^{8}$.

Ще одним питанням, яке розглядається ЄСПЛ в контексті інституту розірвання шлюбу, є питання тривалості розгляду справи про таке розірвання, котре було докладно розглянуто у справі «В.К. проти Хорватії», у рішенні з якої було визнано порушення ст. 12 Конвенції.

Заявник скаржився на те, що тривалий розгляд справи про розлучення порушив його право на повторний шлюб.

Спираючись на попередні рішення, Суд зазначив, що, хоча право на розлучення не випливає зі ст. 12 Конвенції, якщо національне законодавство дозволяє розлучення, воно гарантує для розлучених осіб право на повторний шлюб без необгрунтованих обмежень. У цьому відношенні Суд вважає, що невиконання положень національними органами влади щодо розгляду провадження у справі про розлучення у розумний термін може за певних обставин порушувати питання відповідно до ст. 12 Конвенції.

Щодо цієї справи, Суд встановив, що заявник ініціював процедуру розлучення у національних судах у квітні 2004 р., і що того ж року на першому слуханні, яке відбулося у грудні, сторони погодились, що їх шлюб має бути розірвано. На слуханні, яке відбулося 10 липня 2006 р., заявник просив приєднати до справи про розірвання шлюбу вимогу про оскарження батьківства К. (дитини, народженої у шлюбі), що було погоджено. Однак згодом він неодноразово просив національні суди ухвалити часткове рішення у цій справі про розлучення та щоб інші питання, пов'язані з процедурою розірвання шлюбу, вирішувалися окремо. У зв'язку з цим Суд підкреслює, що національна система передбачає часткове рішення у випадках, коли між сторонами існує домовленість щодо окремого питання у провадженні. Суд також зазначає, що у національному законодавстві немає нічого, що могло б наштовхнути на думку, що це положення не могло бути застосоване у випадку заявника. Однак національні суди або ж відхиляли без будь-яких підстав, або ж ігнорували прохання заявника про часткове рішення понад п’ять років, протягом яких провадження у справі розглядалося судом першої інстанції.

Суд також зазначає, що принаймні двічі, скаржачись на тривалість провадження, заявник повідомляв національні суди, що він планує укласти повторний шлюб, і що тривалий процес розлучення заважає йому це зробити. Він уточнив дату укладення шлюбу в червні 2008 р. і підкреслив, що для нього буде принизливим скасовувати запланований шлюб, оскільки він не міг отримати розлучення через тривалий судовий процес, котрий слід розглядати у світлі релігійних переконань заявника, які він також висловив у своїх скаргах перед національними судами.

Суд вважає, що ці аргументи, викладені заявником, підтверджуються тим, що він справді одружився 3 іншою жінкою незабаром після розірвання попереднього шлюбу.

Відповідно, Суд надав значення тому, що національні органи влади не провели процес розірвання шлюбу ефективно та не врахували конкретні обставини цього провадження, такі як згода сторін на розлу- 
чення, можливість винесення часткового рішення та невідкладний характер цього провадження за внутрішнім законодавством. Отже, за цих конкретних обставин заявник залишався у стані тривалої невизначеності, що створило необгрунтоване обмеження його права на шлюб.

Тому Суд вважає, що було порушення статті 12 Конвенції9.

Винісши подібне рішення, Суд відступив від своєї попередньої практики, на що доречно звернула увагу суддя Берро-Лефевр у своїй Окремій думці, відповідно, не погодившись, що в даній справі було порушення ст. 12 Конвенції ${ }^{10}$.

Зокрема, суддя звертається до рішення у справі «Аресті Хараламбус проти Кіпру». Заявник також скаржився на тривалість розгляду справи про розлучення (п’ять років, сім місяців та 21 день у двох інстанціях) та факт, що це означало, що він не міг вступати в повторний шлюб. Суд, визнаючи, що було порушення ст. 6 Конвенції з точки зору надмірної тривалості судового розгляду, зазначив, що ситуація заявника була не такою, де порушувалася сама суть права на шлюб.

Слід уточнити, що в даній справі заявник зазначив, що заява про розлучення була б легко і швидко розглянута, якби не помилки, допущені національними органами влади в питаннях депортації його колишньої дружини.

Суд вважає, по-перше, що природа справи не була складною. Крім того, хоча деякі відтермінування, зокрема під час провадження у першій інстанції, відбувалися за взаємною згодою сторін, загалом не було великих затримок, пов'язаних із заявником. Що стосується поведінки органів влади, Суд зазначає, що хоча повторний розгляд справи був загалом швидким (чотири місяці та 25 днів), при розгляді судом першої інстанції та на стадії оскарження були значні затримки. Хоча загальна тривалість розгляду у трьох інстанціях, дві з яких однакового рівня юрисдикції, на перший погляд, не виглядає надмірною, Суд вважає, що періоди бездіяльності, які мали місце як у першій інстанції, так і на етапі оскарження, суттєво сприяли затягуванню розгляду справи. На думку Суду, це було невиправданою затримкою, враховуючи характер судочинства та особливу увагу, яка вимагається в таких випадках.

Отже, як зазначалось вище, Суд у даній справі визнав порушення ч. 1 ст. 6 Конвенції, але не права на шлюб (скарга в цій частині була визнана явно необгрунтованою і відхилена), незважаючи на аргументи заявника, що протягом усього часу розгляду справи про розлучення він залишався одруженим, а тому не міг упродовж цього тривалого періоду укласти шлюб і створити сім'ю зі своєю партнеркою на той час. Він заявив, що дані стосунки припинилися, оскільки він не міг знати, коли він зможе укласти новий шлюб11.

Суддя Берро-Лефевр також зазначила, що, ймовірно, не питання тривалості судового розгляду справи про розлучення саме собою викликає запитання за ст. 12, а наявність у цьому контексті обставин настільки специфічних, що вони становлять втручання чи погіршення самої сутності права особи на шлюб. Обставини, визначені Судом як такі, що відрізняють справу «В.К. проти Хорватії» від попередньої практики ССПЛ, а саме: згода сторін на розлучення, можливість винесення часткового рішення та невідкладний характер провадження за внутрішнім законодавством, на думку судді, не є достатніми для порушення будь-якої сутності права на шлюб 12.

Слід зазначити, що як справа «Аресті Хараламбус проти Кіпру», так і справа «В.К. проти Хорватії» більше стосувалися саме надмірної тривалості розгляду справи про розлучення, а не самого права на розлучення як такого.

В аспекті порушення прав при розірванні шлюбу наявна практика ЄСПЛ і проти України. Так, питання фактичної завершеності процедури реєстрації розірвання шлюбу і набуття права на повторний шлюб було розглянуто Судом у справі «Чернецький проти України», де Суд зазначив, що заявник, перебуваючи в ув’язнені, не міг одружитися повторно з іншою жінкою з лютого 2005 р. по жовтень 2008 р., тому що органи влади не змогли завершити реєстрацію розлучення і забезпечити отримання ним Свідоцтва про розірвання шлюбу у в'язниці. Протягом цього періоду органи влади визнали обмеження прав заявника, проте відповідних заходів не вжили. У зв’язку з цим ЄСПЛ постановив, що в даній справі було порушено ст. 12 Конвенції (право на шлюб) у період з лютого 2005 р. по жовтень 2008 р.

Суд також нагадав, що хоча право на розірвання шлюбу не може грунтуватися на ст. 12 Конвенції, якщо національне законодавство передбачає можливість розірвання шлюбу, вона гарантує розлученим особам право на повторний шлюб без необгрунтованих обмежень. Неспроможність національних органів влади здійснити процедуру розірвання шлюбу упродовж розумного строку порушувала за конкретних обставин питання за ст. 12 Конвенції13.

Останнім на даний час рішенням щодо питань про розірвання шлюбу в практиці ЄСПЛ є справа «Бабяж проти Польщі».

У цій справі розглядалась ситуація, коли дружина заявника, котрий мав позашлюбні стосунки, в яких народилася дитина, відмовлялася погодитися на розлучення і у зв'язку з цим розлучення судом не надавалося, адже відповідно до польського законодавства, заява про розлучення не підлягає задоволенню, якщо іiі подає той з подружжя, хто винен у розпаді шлюбу, тоді як невинний з подружжя згоди на розлучення не дає за умови, що ненадання такої згоди не суперечить розумним принципам соціального співіснування.

При розгляді даної справи було докладно проаналізовано польську судову практику 3 даного питання. Так, польськими судами розглянуто багато справ, які стосуються ситуацій, коли один 3 подружжя-відповідач відмовляється давати згоду на розлучення. Зокрема, суди вважають, що невинний відповідач має право відмовити у наданні згоди. Презумпція сумлінності застосування такої відмови визнається доти, доки не буде доведено, посилаючись на конкретні обставини справи, що відмова суперечить принципам суспільного співіснування відповідно до змісту ст. 5 Цивільного кодексу Польщі. Зокрема, намір одного 3 подружжя-відповідача зірвати плани заявника щодо формалізації його позашлюбних відносин сам по собі не повинен вва- 
жатися несумісним із цими принципами, якщо було доведено, що відмова була зумовлена бажанням продовжувати шлюб, що відповідає етичним та соціальним нормам.

Заявник у справі скаржився, що згідно зі ст. ст. 8 та 12 Конвенції, відмовивши у задоволенні позову про розлучення, органи влади перешкодили йому одружитися 3 жінкою, з якою він проживав.

У цій справі національні суди детально вивчили факти у відповідному контексті національного законодавства. Під час розгляду справи про розлучення було зібрано вичерпні докази. Заявник мав можливість викласти свою позицію в суді та поставити запитання свідкам. Рішення суду першої інстанції було переглянуто апеляційним судом. Обгрунтування цього рішення містило детальне пояснення інтересів, які були враховані, як оцінювались докази та які були підстави для прийняття рішення про відхилення заяви про розірвання шлюбу.

Суду добре відомо, що у заявника була дочка з іншою жінкою, що він, очевидно, був у стабільних стосунках і що національні суди визнали повний і безповоротний розрив його шлюбу. Проте розглядати дану ситуацію протилежно означало б, що вимога про розлучення повинна бути задоволена незалежно від процесуальних та матеріальних норм внутрішнього законодавства про розлучення, щодо особи, яка просто вирішила залишити іншого з подружжя та народити дитину з новим партнером. Хоча, згідно зі ст. 8 Конвенції, фактичні сім’ї та стосунки захищені, такий захист не означає, що їм слід надавати особливе юридичне визнання.

Суд також зазначає, що не було аргументовано, що відповідно до польського законодавства відмова в наданні розлучення унеможливлює заявника подати нове клопотання про розірвання шлюбу до суду на більш пізньому етапі, якщо і коли обставини зміняться.

На думку Суду, якщо положення Конвенції не можуть тлумачитися як гарантування можливості, згідно з національним законодавством, отримати розлучення, ці положення не можуть, тим більше, тлумачитися як гарантування сприятливого результату в процесі розлучення, порушеного відповідно до положення закону, що дозволяє розлучення.

Враховуючи вищезазначене, Суд визнав, що не було порушення ні ст. 8, ні ст. 12 Конвенції 14.

Схожою була ситуація у справі «Анджей Піотровський проти Польщі», в якій дружина також не надавала згоди на розлучення винному у позашлюбному зв'язку чоловікові, пробачивши йому зраду.

У цій справі аргументація була загалом така сама, як у справі «Бабяж проти Польщі», проте у даному випадку Суд визнав заяву неприйнятною. Слід зазначити, що у справі Піотровського, на відміну від справи Бабяжа, хоча заявник і скаржився у своїй заяві на те, що відмова у наданні розлучення унеможливила для нього укладення повторного шлюбу, було зазначено, що ані в процесі розгляду справи про розлучення, ані в Суді не було надано фактів про підтвердження існування стабільних і тривалих стосунків 3 іншою жінкою. Заявник просто назвав свої стосунки з нею життєздатними. Він також не посилався перед Судом на будь-які конкретні плани щодо укладення шлюбу, зірвані відмовою надати розлучення. Навпаки, він заявив, що не бажає знову одружуватися. Не було доведено, що відсутність розлучення та юридична фікція його триваючого шлюбу заважають йому повною мірою насолоджуватися особистим життям ${ }^{15}$.

Висновки. Отже, підходи ЄСПЛ в питаннях розірвання шлюбу можна звести до таких положень:

1. Суд дотримується практики прямого невизнання права на розірвання шлюбу, як такого, що походить 3 положень Конвенції: ні ст. 12 (право на шлюб), ні ст. 8 (право на повагу до приватного і сімейного життя) Конвенції не можуть тлумачитись як такі, що надають особам право на розлучення.

2. Оскільки положення Конвенції не гарантують можливості, згідно з національним законодавством, отримати розлучення, вони не можуть, тим більше, тлумачитися як такі, що гарантують сприятливий результат для позивача в процесі розгляду справ про розлучення, порушеного відповідно до положення закону, що дозволяє розірвання шлюбу.

3. Якщо національне законодавство дозволяє розлучення, що не є вимогою Конвенції, ст. 12 забезпечує розлученим особам право на повторний шлюб без необгрунтованих обмежень.

4. Неспроможність національних органів влади здійснити процедуру розірвання шлюбу упродовж розумного строку порушує за конкретних обставин питання за ст. 12 Конвенції. Так, у рішенні у справі «В.К. проти Хорватії», керуючись наявністю згоди сторін на розлучення, можливістю винесення часткового рішення та невідкладним характером провадження за внутрішнім законодавством Суд визнав порушення ст. 12 Конвенції. Проте у подібних попередніх справах ЄСПЛ визнавав лише порушення ст. 6 Конвенції 3 точки зору надмірної тривалості судового розгляду справ про розлучення, тоді як суть права на шлюб, на думку Суду, не порушувалася.

1 Про виконання рішень та застосування практики Європейського суду з прав людини: Закон України від 23 лютого 2006 p. № 3477-IV. URL: https://zakon.rada.gov.ua/laws/show/3477-15\#Text

2 Конвенція про захист прав людини і основоположних свобод від 4 листопада 1950 p. URL: https://zakon.rada.gov.ua/laws/ show/995 004\#Text

3 Сімейний кодекс України від 10 січня 2002 року № 2947-III. URL: https://zakon.rada.gov.ua/laws/show/2947-14\#Text

4 Johnston and Others v. Ireland, Application no. 9697/82 18 December 1986, §§ 50, 52 URL: http://hudoc.echr.coe.int/eng?i= $001-57508$

5 Bart van der Sloot. Between Fact and Fiction: an Analysis of the Case Law on Article 12 ECHR / Draft version: final version published in Child and Family Law, 2014-4. P. 11. URL: https://www.ivir.nl/publicaties/download/1561.pdf

6 Протокол № 7 до Конвенції про захист прав людини і основоположних свобод (Протокол вступив в силу 1 листопада 1988 року). URL: https://zakon.rada.gov.ua/laws/show/994_804\#Text

7 Johnston and Others v. Ireland, Application no. 9697/82 18 December 1986, §§ 53, 54. URL: http://hudoc.echr.coe.int/eng?i= $001-57508$ 


\section{Проблеми цивільного, господарського, трудового права та права соціального забезпечення}

${ }^{8}$ F. v. Switzerland, no. 11329/85, $\S \S 36,38,40,18$ December 1987. URL: http://hudoc.echr.coe.int/eng?i=001-57490 114778

9 V.K. v. Croatia, no. 38380/08, $\S \S 94,99,101-103,106,107,27$ November 2012. URL: http://hudoc.echr.coe.int/eng?i=001-

10 Partially Dissenting Opinion of Judge Berro-Lefevre in case V.K. v. Croatia, no. 38380/08, 27 November 2012. URL: http://hudoc.echr.coe.int/eng?i=001-114778 81807

${ }^{11}$ Aresti Charalambous v. Cyprus, no. 43151/04, $\S \S 42,45,46,54,56,19$ July 2007. URL: http://hudoc.echr.coe.int/eng?i=001-

12 Partially Dissenting Opinion of Judge Berro-Lefevre in case V.K. v. Croatia, no. 38380/08, 27 November 2012. URL: http://hudoc.echr.coe.int/eng?i=001-114778

13 Chernetskiy v. Ukraine, no. 44316/07, § 30, 31, 8 December 2016. URL: http://hudoc.echr.coe.int/eng?i=001-169216

14 Babiarz v. Poland, no. 1955/10, § 28, 32, 53-56, 58, 10 January 2017. URL: http://hudoc.echr.coe.int/eng?i=001-170344

15 Andrzej Piotrowski v. Poland, no. 8923/12, § 51, 22 November 2016. URL: http://hudoc.echr.coe.int/eng?i=001-169916

\section{Резюме}

Білик О.О. Питання, пов'язані з розірванням шлюбу, в практиці Європейського суду з прав людини.

Стаття присвячена розгляду практики Європейського суду з прав людини в контексті можливості осіб розірвати шлюбні відносини та інших, пов'язаних з розірванням шлюбу, питань.

У статті проаналізовано низку рішень Суду, в яких розглядалося дане питання з різних аспектів. Зокрема, визнання права на розлучення як такого, коли національне законодавство забороняло розірвання шлюбного зв'язку за життя обох 3 подружжя; наявність обмежень для особи укласти повторний шлюб після розірвання попереднього; надмірна тривалість розгляду справи про розлучення, що, в свою чергу, супроводжувалося невизначеністю правового статусу осіб; неможливість особи розірвати шлюб у зв'язку з тим, що інший з подружжя-відповідач не дає згоди на розлучення.

Ключові слова: право на шлюб, розірвання шлюбу, право на повторний шлюб, позашлюбні стосунки, Конвенція про захист прав людини і основоположних свобод, практика Європейського суду з прав людини.

\section{Резюме}

Билык А.O. Вопросы, связанные с расторжением брака, в практике Европейского суда по правам человека.

Статья посвящена рассмотрению практики Европейского суда по правам человека в контексте возможности лиц разорвать брачные отношения и других, связанных с расторжением брака, вопросов.

В статье проанализирован ряд решений Суда, в которых рассматривался данный вопрос с разных аспектов. В частности, признание права на развод как такового, когда национальное законодательство запрещало расторжение брачной связи при жизни обоих супругов; наличие ограничений для лица заключить повторный брак после расторжения предыдущего; чрезмерная продолжительность рассмотрения дела о разводе, что, в свою очередь, сопровождалось неопределенностью правового статуса лиц; невозможность лица расторгнуть брак в связи с тем, что другой из супругов-ответчик не дает согласия на развод.

Ключевые слова: право на брак, расторжение брака, право на повторный брак, внебрачные отношения, Конвенция о защите прав человека и основных свобод, практика Европейского суда по правам человека.

\section{Summary}

Oleksandra Bilyk. Issues concerning divorce in European Court of Human Rights case law.

The article deals with the case law of the European Court of Human Rights in the context of the individuals' possibility to dissolve one's marriage in general and other issues related to divorce.

Starting with the case of Johnston and Others v. Ireland (1986) ECHR made it clear that a right to divorce cannot be derived from Article 12 of the Convention (Right to marry). The Court stated that drafters of the Convention had no intention to include in Article 12 any guarantee of a right to have the ties of marriage dissolved by divorce. On the other hand, in case of F. v. Switzerland (1987) ECHR stated that if national legislation allows divorce, which is not a requirement of the Convention, Article 12 secures for divorced persons the right to remarry without unreasonable restrictions.

In more recent cases the Court dealt with issues concerning the lengthy divorce proceedings that impaired applicants' right to marry again. In this aspect the Court would not exclude that a failure to conduct divorce proceedings within a reasonable time could in certain circumstances raise an issue under Article 12 of the Convention. However, in such cases the Court emphasizes more on the issue of the violation of Article $6 \S 1$ of the Convention in light of the failure of the domestic authorities to conduct the divorce proceedings efficiently.

Another side of divorce proceedings was reviewed in case of Babiarz v. Poland (2017) where the applicant complained that by refusing to grant him a divorce the authorities had prevented him from marrying the woman with whom he had been living and had a child. The situation arose due to the provisions of Polish law that a divorce could not be granted if it had been requested by the party whose fault it was that the marriage had broken down, if the other party refused to consent. In the Court's view, if the provisions of the Convention cannot be interpreted as guaranteeing a possibility, under domestic law, of obtaining divorce, they cannot, a fortiori, be interpreted as guaranteeing a favourable outcome in divorce proceedings instituted under the provision of that law allowing for a divorce.

Key words: right to marry, divorce, right to remarry, extramarital relationship, Convention for the Protection of Human Rights and Fundamental Freedoms, European Court of Human Rights case law. 